\title{
Vessel Failure Indicator
}

National Cancer Institute

\section{Source}

National Cancer Institute. Vessel Failure Indicator. NCI Thesaurus. Code C119557.

An indication as to whether vessel failure occurred. 